\title{
Pengaruh Budaya Organisasi Terhadap Kinerja Anggota (Survei Badan Eksekutif Mahasiswa Program Studi Ilmu Komunikasi Universitas Negeri Jakarta)
}

\author{
${ }^{1}$ Hana Aviela Fedria Wowor, ${ }^{2}$ Kiki Dwi Arviani, ${ }^{3}$ Salsa Ratu Maisya \\ ${ }^{123}$ Program Studi Ilmu Komunikasi ,Universitas Negeri Jakarta, Indonesia \\ email : HanaAvielaFedriaWowor_1410619007@mhs.unj.ac.id
}

\begin{abstract}
Abstrak
Badan Eksekutif Mahasiswa salah satu lembaga kemahasiswaan atau organisasi yang berada pada universitas guna menunjang prestasi dan minat bakat mahasiswa. Sama seperti organisasi pada umumnya, lembaga kemahasiswaan juga memiliki budaya yang dipegang oleh setiap anggota, yang kemudian menjadi identitas tersendiri. Penelitian ini hendak mencari tahu apakah ada pengaruh dari budaya organisasi terhadap kinerja anggota Badan Eksekutif Mahasiswa pada Program Studi Ilmu Komunikasi Universitas Negeri Jakarta. Dalam penelitian terdapat populasi, yaitu anggota BEMP Ilmu Komunikasi Universitas Negeri Jakarta yang berjumlah 67 orang dengan non probability sampling jenis purposive sampling, kemudian dengan rumus Slovin menghitung banyaksampel yang diperlukan, yaitu berjumlah 53 orang. Analisis regresi linear sederhana digunakan dalam penelitian ini untuk menganalisis data yang terkumpul yang mana hasilnya menunjukkan ada pengaruh dari budaya organisasi terhadap kinerja anggota BEMP Ilmu Komunikasi di Universitas Negeri Jakarta yang dapat dilihat dari hasil analasis regresi, nilai $\mathrm{F}$ hitung berjumlah 33,321 dan signifikansi berjumlah $0,000<0,005$ sehingga dapat disimpulkan bahwa variabel $\mathrm{X}$, yaitu pengaruh budaya organisasi memberikan pengaruh terhadap variabel $\mathrm{Y}$, yaitu kinerja anggota.
\end{abstract}

Kata Kunci :budaya, organisasi, kinerja

\begin{abstract}
The Student Executive Board is one of the student organizations or organizations at the university to support the achievements and interests of students' talents. Just like organizations in general, student organizations also have a culture that is held by each member, which then becomes a separate identity. This study intends to find out whether there is an influence of organizational culture on the performance of the Student Executive Board members at the Communication Science Study Program, State University of Jakarta. In the study, there was a population, namely members of BEMP Communication Science, State University of Jakarta, totaling 67 people with a nonprobability sampling type of purposive sampling, then using the Slovin formula calculated the number of research samples needed, which was 53 people. Simple linear regression analysis was used in this study to analyze the collected data where the results showed that there was an influence of organizational culture on the performance of BEMP Communication Sciences members at the State University of Jakarta which can be seen from the results of regression analysis, the calculated $F$ value was 33.321 and the significance was 0.0000 .005 so it can be concluded that variable $X$, namely the influence of organizational culture, has an influence on variable $Y$, namely the performance of members.
\end{abstract}

Keywords :culture, organization, performance 


\section{PENDAHULUAN}

Hingga sampai saat ini pendidikan masih tetap dipercayai sebagai salah satu bidang yang dipercaya dapat merealisasikan intelegensi dan sifat dasar manusia sehingga semakin baik. Pemerintah memberikan danatiap tahunnya dalam bidang pendidikan yang mana berkisar sebanyak $20 \%$ dari total belanja. Maka dari itu, dapat dibuktikan bahwasanya pendidikan merupakan suatu yang utama dalam menciptakan generasi penerus yang cerdas sekaligus berguna bagi bangsa dan negara (Muslianti 2018).

Pendidikan salah satu usaha yang dilakukan nyata dan direncanakan guna membentuk situasi dan proses belajar dan mengajar yang mana siswa ataupun siswi bisa dengan aktif meningkatkankemampuan dalam dirinya, memiliki keadaan rohaniatau keagamaan yang baik, dapat mengendalikan diri, memiliki sikap, intelegensi dan berbudi pekerti, dan mempunyai suatu keahlian yang menarik untuk kebutuhan pribadi, lingkungan sosial, bangsa, serta untuk negara (Muslianti 2018).

Hal tersebut dijelaskan secara lengkap dalam UU No. 20 Tahun 2003 mengenai Sistem Pendidikan Nasional pada Bab 1 Pasal 3. Kemudian, dalam Undang-Undang RI mengenai Pendidikan Tinggi pada paragraf ketiga tentang Organisasi Kemahasiswaan Pasal 77 Ayat 1 menyatakan bahwa mahasiswa dapat membuat suatu badan organisasi kemahasiswaan. Lalu, pada ayatnya yang kedua dijelaskan mengenai beberapa fungsi sebuah organisasi kemahasiswaan, antara lain (1) sebagai wadah untuk meningkatkan minat, bakat, dan kemampuan; (2) menambah kreativitas, sikap peduli, berpikir kritis, berani, berjiwa pemimpin, dan berkebangsaan; (3) menjadi sarana yang dapat digunakan untuk kepentingan dan kesejahteraan mahasiswa; (4) meningkatkan rasa tanggung jawab di lingkungan sosial, seperti kegiatan pengabdian pada masyarakat.

Pada kalangan mahasiswa, organisasi dikenal dengan lembaga kemahasiswaan. Organisasi dapat digolongkan ke dalam dua jenis, yakni organisasi yang berada dalam lingkungan universitas dan organisasi yang berada di luar universitas. Universitas Negeri Jakarta (UNJ) adalah salah satu perguruan tinggi yang didalamnya terdapat organisasi, yang diharapkan dapat memberikan fasilitas kepada mahasiswa sehingga mampu menggali dan mengembangkan bakat mahasiswa dan budaya yang berada dalam organisasi mampu diterima dengan baik oleh mahasiswa.

Salah satu organisasi atau lembaga kemahasiswaan yang ada pada Universitas Negeri Jakarta adalah Badan Eksekutif Mahasiswa. Setiap fakultas sampai program studi di Universitas Negeri Jakarta memiliki satu badan eksekutif mahasiswa untuk mewadahi setiap mahasiswa dalam berorganisasi dan menyalurkan bakat, serta minat para mahasiswa. Badan Eksekutif Mahasiswa Program Studi Ilmu Komunikasi adalah salah satu lembaga kemahasiswaan UNJ yang berada pada jurusan ilmu komunikasi yang berada pada Fakultas Ilmu Sosial.

BEMP Ilmu Komunikasi memiliki visi untuk menjadi tempat bagi mahasiswa program studi Ilmu Komunikasi UNJ untuk meningkatkan kapabilitas diri dalam berorganisasi serta berprestasi agar terbentuk program studi Ilmu Komunikasi UNJ yang lebih baik. Adapun visi tersebut dijalankan dengan misi (1) memperkuat hubungan internal, yaitu antar anggota BEMP Ilmu Komunikasi UNJ agar memiliki sense of belonging; (2) membentuk kader mahasiswa Ilmu Komunikasi UNJ sehingga ada kredibilitas dalam berorganisasi agar BEMP Ilmu Komunikasi semakin baik, (3) memjalankan komunikasi yang efektif dan efisien di antara anggota BEMP Ilmu Komunikasi.

Sama halnya dengan organisasi pada umumnya, BEMP Ilmu Komunikasi memiliki budaya yang dianut setiap anggotanya. Budaya dapat dijadikan sebagai bentuk dari identitas dalam berorganisasi sehingga bisa menciptakan sebuah pengaruh yang baik maupun menimbulkan pengaruh yang baik. Untuk mencapai hal tersebut, organisasi harus melakukan perubahan pandangan yang lama menjadi pandangan baru agar lebih produktif serta memberikan fungsi bagi mahasiswa.

Adanya budaya dalam organisasi membantu anggota untuk memiliki nilai, norma, pedoman, serta acuan dalam melaksanakan dan mewujudkan visi dan misi dalam organisasi. Selain itu, budaya adalah 
pemersatu, peredam masalah, serta menjadi dorongan bagi anggota organisasi dalam melaksanakan tugas.

Budaya yang baik dan kuat akan berpengaruh positif pada kinerja anggota untuk kurun waktu yang lama. Mak dari itu , budaya dalam sebuah organisasi sangat memegang peran yang begitu sangat penting dalam kesuksesan suatu organisasi (Pratama 2012). Pada sebuah penelitian terdahulu oleh Jamaludin (2017)yangberjudul "Pengaruh Budaya Organisasi Terhadap Kinerja Pegawai Pada Dinas Pendidikan Provinsi Sulawesi Selatan" bertujuan untuk dapat mengetahui pengaruh dari budaya organisasi kantor dinas pendidikan Sulawesi Selatan terhadap kinerja setiap pegawainya. Penelitian ini menggunakan analisis data deskriptif, menguji normalitas data, menggunakanproduct moment correlation, sertaanalisis regresi linear sederhana. Hasilnya menunjukkan terdapat pengaruh dari budaya organisasi di dinas pendidikan Sulawesi Selatan kepada kinerja setiap pegawainya(Jamaluddin et al. 2017).

Penelitian sejenis lainnya, yaitu "Pengaruh Budaya Organisasi Terhadap Kinerja Karyawan (Studi Pada Karyawan PT Karya Indah Buana Surabaya)" yang dikerjakan Rodiathul Kusuma Wardani, bersama M. Djudi Mukzam, dan Yuniadi Mayowan pada tahun 2016. Tujuan penelitiannya adalah menjelaskan pengaruh antar variabel secara simultan dan parsial dari asas integritas dan asas keakraban, yang merupakan variabel dari Budaya Organisasi kepada variabel Kinerja Karyawan. Pada penelitian tersebut digunakan pendekatan kuantitatif dan metode explanatoryresearch. Secara simultan hasil penelitian menperlihatkan bahwa budaya organisasi, yaitu asas keakraban dan asas integritas memilikisecara signifikan berpengaruh kepada kinerja karyawan (Wardani, Mukzam, and Mayowan 2016).

Penelitian terdahulu lainnya dilakukan oleh Ezra Zhafran Giani Muhammad bersama Mochammad Djudi Mukzam (2017) yang mana berjudul "Pengaruh Budaya Organisasi Terhadap Karyawan (Studi pada Karyawan Bank BRI Kantor Cabang Tuban)”. Tujuannya guna melihat apakah baik secara simultan maupun parsial, budaya organisasi berpengaruh kepada kinerja karyawan. Untuk menganalisis data digunakan analisis statistic deskriptif dan inferensial. Analisis data yang dilakukanmemperlihatkan hasil bahwa budaya organisasi Bank BRI di Kantor Cabang Tuban berpengaruh pada kinerja setiap karyawan (Muhammad and Mukzam 2017).

Huntington mengatakan bahwa budaya dalam sebuah organisasi akan menjadi penentu kemajuan organisasi tersebut. Budaya dalam organisasi memiliki pengaruh terhadap cara bekerja setiap anggota organisasi. Selain itu, memengaruhi kesatuan dalam persepsi dalam melaksanakan tugas-tugas dalam organisasi. Budaya organisasi ini sangat berkaitan dengan pemberdayaan pegawai, karena budaya membantu meningkatkan motivasi dalam diri anggota untuk menggunakan kesempatan yang ada dalam organisasinya sebaik mungkin dengan mengerahkan kemampuan yang terbaik (Pratama 2012). Menurut Robbin budaya dalam sebuah organisasi dapat dikatakan sebagai sebuah seperangkat makna bersama yang dijadikan pegangan setiap individu di dalam organisasi sehingga membedakannya dengan anggota organisasi yang lainnya. Jika diamati, sistem makna bersama yang disebutkan adalah seperangkat ciri-ciri yang dihargai oleh organisasi tersebut (Marliani 2019).

Budaya organisasi memiliki fungsi, yakni memberikan batasan dalam mendefinisikan peran sehingga organisasi tersebut memiliki perbedaan yang jelas, memberikan pengertian jati diri kepada suatu hal yang lebih besar daripada ketertarikan perorangan, serta memperlihatkan sistem sosial yang stabil di mana budaya organisasi bisa membangun pola pikir dan membentuk perilaku terhadap tiap anggota dalam organisasi (Amanda, Budiwibowo, and Amah 2017).

Terdapat beberapa ciri-ciri dasar dalam budaya organisasi yang dinyatakan oleh Robbins dan Coulter, yaitu inovasi dan pengambilan resiko, menampilakan atau memperlihatkan hal-hal mendetail, berpusat pada hasil, berpusat pada individu, berpusat pada kelompok, anggota organisasi yang bersemangat, serta keadaadan organisasi yang stabil (Sagita, Susilo, and Cahyo 2018).

Kinerja adalah konsep pada manajemen sumber daya manusia yang dapat dipengaruhi oleh 
banyak hal, salah satunya oleh budaya dalam organisasi. Pernyataan Miner menjelaskan bahwa kinerja merupakan harapan kepada individu agar bisa berperan maupun berperilaku sesuai dengan tugas yang diberikan, sehingga keberhasilan dalam sebuah organisasi untuk mencapai tujuannya memiliki atau tergantung kepada kinerja dalam setiap anggota organisasi. Penilaian kinerja memiliki tujuan untuk memperoleh informasi tentang situasi kinerja, konflik ataupun tantangan dalam pekerjaan. Informasi tersebut dapat dipakai oleh manajemen dalam penentuan setiap karir anggota organisasi. Penilaian tersebut, seperti kualitas kerja yang dicapai, banyaknya pekerjaan yang dapat dikerjakan dalam periode yang ditetapkan, pemahaman mengenai pekerjaan, kreativitas, kerja sama, inisiatif, ketergantungan dan kualitas personal (Rizaldi 2019).

Dari latar belakang tersebut bahwasanya penelitian ini hendak mencari tahu apakah ada pengaruh dari budaya organisasi kepada kinerja setiap anggotanya, khususnya anggota BEMP Ilmu Komunikasi UNJ, sehingga peneliti merumuskan permasalah pada penelitian ini adalah "Bagaimana pengaruh budaya organisasi terhadap kinerja anggota pada Badan Eksekutif Mahasiswa Program Studi Ilmu Komunikasi di Universitas Negeri Jakarta?" dengan tujuan untuk mengetahui bagaimana budaya suatu organisasi berpengaruh terhadap kinerja anggota Badan Eksekutif Mahasiswa Program Studi Ilmu Komunikasi di Universitas Negeri Jakarta.

\section{METODE}

Dalam suatu penelitian ada dua pendekatan yang dapatdipakai guna mendapatkan jawaban dari pertanyaan dalam penelitian, dua pendekatan tersebut adalah pendekatan kualitatif dan kuantitatif. Penelitian ini hendak mencari tahu hubungan antara budaya organisai dengan kinerja anggota organisasi tersebut. Oleh karena itu, peneliti menggunakan pendekatan kuantitatif, yaitu pendekatan yang dilakukan untuk menguji teori serta menguji hubungan antar variabel yang terdapat dalam penelitian (Creswell 2014). Terdapat dua konsep yang digunakan, yaitu budaya dan kinerja, dengan variable independen adalah budaya organisasi dan variable dependen adalah kinerja anggota. Variabel budaya organisasi terdiri dari beberapa dimensi yang diambil dari karakteristik suatu budaya organisasi menurut Robbins. Karakteristik tersebut diantaranya adalah individu yang berinisiatif, dapat menoleransi langkah berisiko, adanya arahan yang jelas, kesatuan, mendapat dukungan oleh manajemen, kontrol, identitas, sistem timbal balik, dapat menoleransi suatu permasalahan, serta terdapat alur komunikasi (Pratama 2012). Masing-masing dimensi diturunkan menjadi dua indikator. Individu yang berinisiatif diturunkan menjadi kebebasan mengemukakan pendapat dan kebebasan untuk berinisiatif dan bekerja. Dapat menoleransi langkah berisiko diturunkan menjadi diberi kesempatan bertindak aktif dalam pekerjaan dan kebebasan berinovatif. Adanya arahan yang jelas diturunkan menjadi adanya standar kerja yang jelas dalam organisasi dan prestasi yang diharapkan diberitahukan secara jelas. Kesatuan diturunkan menjadi adanya koordinasi antar unit dalam organisasi dan terdapat kerja sama dalam unit. Dukungan oleh manajemen diturunkan menjadi komunikasi dengan ketua atau atasan dan dukungan dari ketua atau atasan. Kontrol diturunkan menjadi adanya sistem pengawasan dan peraturan yang tegas dalam organisasi. Identitas diturunkan menjadi rasa bangga pada organisasi serta bagiannya, dan mengetahui nilai-nilai dan/atau budaya dalam organisasi. Sistem timbal balik diturunkan menjadi kebijakan organisasi dalam sistem imbalan dan prestasi untuk anggota. Toleransi pada suatu permasalahan diturunkan menjadi dapat menyelesaikan masalah di kampus dan bebas mengutarakan kritik. Kemudian, alur komunikasi diturunkan menjadi komunikasi antara bagian-bagian dalam organisasi dan mensosialisasikan kebijakan bagi para anggota. Kemudian, variabel kinerja anggota menggunakan pengukuran yang dikemukakan oleh Gomez.

Tolak ukur tersebut menurut Gomez dapat digunakan untuk penelitian terkait kinerja pegawai 
(Pratama 2012). Pengukuran yang dimaksud antar lain adalahquality of work (mutu pekerjaan), quantity of work (jumlah pekerjaan), job knowledge (pengetahuan pekerjaan), creativeness (kreativitas), cooperative (kooperatif), initiative (inisiatif), dependability (dapat dipercaya), danpersonal qualities (kualitas diri). Quality of work diturunkan menjadi kemampuan anggota untuk menyelesaikan tugas dan melakukan tugas yang diberi sesuai tahapan. Quantity of work diturunkan menjadi ketepatan waktu dalam menyelesaikan tugas dan menyelesaikan tugas sesuai target yang hendak dicapai. Job knowledge diturunkan menjadi tingkat pengetahuan mengenai tugas yang dikerjakan dan mempunyai keterampilan yang dibutuhkan dalam menyelesaikan tugas tersebut. Creativeness diturunkan menjadi memiliki gagasan atau ide terkait dengan tugas dan bertindak kreatif dalam menyelesaikan masalah yang terjadi. Cooperative diturunkan menjadi mampu bekerjasama dengan rekan atau sesama anggota dalam menyelesaikan tugas bersama dan kesediaan menerima nasihat, masukan, serta pendapat dari rekan atau sesama anggota. Initiative diturunkan menjadi anggota berinisiatif untuk mengerjakan tugas dan bersemangat membereskan tugas-tugas yang baru. Dependability diturunkan menjadi kesadaran pentingnya kehadiran dan kemampuan untuk memberi penjelasan terkait tugas yang dikerjakan. Personal qualities diturunkan menjadi kejujuran anggota dan berpenampilan yang sopan dan baik di kampus.

Populasi penelitian ini merrupakan anggota Badan Eksektutif Mahasiswa Prodi Ilmu Komunikasi UNJ sebanyak 67 anggota. Adapun sampel merupakan sebagian dari populasi tersebut. Ukuran sampel dalam penelitian ini adalah sebanyak 53 sampel dihitung dengan menggunakan rumus Slovin. Peneliti menggunakan non probability sampling untuk menarik sampel, di mana teknik ini digunakan karena tidak dapat memperkirakan peluang terpilihnya sampel. Penarikan sampel dibatasi pada kriteria tertentu atau disebut purposive sampling(Sekaran and Bougie 2016). Dalam penelitian ini, kriteria yang dicari oleh peneliti adalah anggota Badan Eksekutif Mahasiswa Prodi Ilmu Komunikasi UNJ.

Survei, yaitu metode yang digunakan untuk memperoleh penjelasan mengenai suatu tren, sikap ataupun pendapat sebuah populasi melalui sampel dari populasi tersebut (Creswell 2014). Dalam metode penelitian survei, peneliti menggunakan instrumen berupa kuesioner untuk memperoleh data yang diperlukan. Kuesioner adalah satu dari banyak teknik mengumpulkan data, teknik ini dilakukan dengan menyebar pertanyaan atau pernyataan tertulis pada responden yang sesuai(Neuman 2014). Kuesioner disebar melalui google formulir kepada responden yang merupakan anggotan BEMP Ilmu Komunikasi UNJ dengan jumlah 20 pertanyaan, di mana masing-masing variabel terdapat 10 pertanyaan dan menggunakan skala interval dengan pilihan sangat tidak setuju sampai sangat setuju.

Dalam pengujian validitias data yang diperoleh digunakan analisis Kaiser-Meyer-Olkin (KMO) Measure of Sampling Adequacy dengan program SPSS terhadap masing-masing variabel. Dalam pengukuran KMO, variabel dikatakan valid apabila berada di antara nilai 0,5 dan 1,0. Sedangkan, untuk uji reliabilitas digunakan Cronbach's Alpha, yang mana batas nilai perlu lebih dari 0,6 untuk mendapat data yang reliabel(Malhotra 2010). Kemudian, analisis regresi linear digunakan gunamelihat apakah ada hubungan dua variable yang diteliti.

\section{HASIL DANPEMBAHASAN \\ Tabel 1. Validitas Variabel Budaya Organisasi $(\mathrm{X})$ KMO and Bartlett's Test}

\begin{tabular}{lcr}
\hline Kaiser-Meyer-Olkin Measure of Sampling &, 780 \\
Adequacy. & & \\
Bartlett's Test of & Approx. Chi-Square & 199,018 \\
Sphericity & Df & 45 \\
& Sig. &, 000 \\
\hline
\end{tabular}


Validitas suatu skala adalah mengukur seberapa jauh atau besar perbedaan nilai skala yang dteliti. Menunjukkan perbedaan jarak sebenarnya pada objek suatu karakteristik yang diukur, daripada kesalahan sistematik atau acak (Malhotra, 2010). Kaiser-Meyer-Okin (KMO) merupakan indikator yang digunakan untuk memeriksa atau menganalisis kesesuaian. Nilai yang tertinggi, yaitu diantara 0,5 dan 1,0 menandakan bahwa analisis suatu faktor sesuai. Sedangkan, nilai yang berada di bawah 0,5 dapat diartikan bahwa analisis suatu faktor mungkin tidak sesuai (Malhotra, 2010). Pada tabel 1 terlihat nilai KMO variabel $\mathrm{X}$ berjumlah 0,780 > 0,5 sehingga variabel budaya organisasi valid.

Tabel 2. Validitas Variabel Kinerja Anggota (Y)

KMO and Bartlett's Test

\begin{tabular}{lcr}
\hline Kaiser-Meyer-Olkin Measure of Sampling &, 778 \\
Adequacy. & & \\
Bartlett's Test of & Approx. Chi-Square & 295,003 \\
Sphericity & df & 45 \\
& Sig. &, 000 \\
\hline
\end{tabular}

Pada tabel 2 terlihat hasil KMO variabel Y berjumlah 0,778 > 0,5 sehingga variabel kinerja anggota valid.

Tabel 3. Reliabiltas Variabel Budaya Organisasi (X)

\begin{tabular}{rr}
\hline $\begin{array}{c}\text { Cronba } \\
\text { ch's Alpha }\end{array}$ & $\begin{array}{r}\mathrm{N} \\
\text { of Items }\end{array}$ \\
\hline, 844 & 10 \\
\hline
\end{tabular}

Reliabilitas merupakan analisis yang dilakukan untuk melihat seberapa jauh skala memperoleh nilai tetap atau yang konsisten apabila pengukuran dilakukan secara berulang (Malhotra, 2010). Cronbach's alpha merupakan hasil rata-rata semua kemungkinan koefisien yang diperoleh dari cara yang beragam ketika memisahkan item skala, koefisien ini beragam dimulai dari skor 0 hingga 1, dan skor 0,6 atau kurang di mana secara umum menunjukkan konsistensi reliabilitas internal yang tidak memadai (Malhotra, 2010). Pada tabel 3 terlihat hasil reliabiltas cronbach's alpha variabel X 0,844>0,6 yang berarti variabel budaya organisasi reliabel.

Tabel 4. Reliabilitas Variabel Kinerja Anggota (Y)

\begin{tabular}{ll}
\hline $\begin{array}{l}\text { Cronbach's } \\
\text { Alpha }\end{array}$ & N of Items \\
\hline, 887 & 10 \\
\hline
\end{tabular}

Variabel kinerja anggota reliabel dapat dilihat dari tabel 4 dimana nilai cronbach's alphanya berjumlah 0,887 > 0,6 sehingga variabel kinerja anggota reliabel. 


\section{Tabel 5}

ANOVA $^{\mathrm{a}}$

\begin{tabular}{|c|c|c|c|c|c|c|}
\hline Model & & $\begin{array}{l}\text { Sum of } \\
\text { Squares }\end{array}$ & $\mathrm{df}$ & Mean Square & $\mathrm{F}$ & Sig. \\
\hline \multirow[t]{3}{*}{1} & Regression & 280,272 & 1 & 280,272 & 33,321 &, $000^{\mathrm{b}}$ \\
\hline & Residual & 428,973 & 51 & 8,411 & & \\
\hline & Total & 709,245 & 52 & & & \\
\hline
\end{tabular}

a. Dependent Variable: Kinerja Anggota

b. Predictors: (Constant), Budaya Organisasi

Menurut Muhidin dan Abdurahman (2017:187) (Imron 2019). Tujuan dari analisis regresi, yaitu untuk mengetahui hubungan diantara kedua variabel maupun lebih, khususnya dipergunakan untuk mengetahui pola hubungan dan mengetahui variasi pada variabel bebas yang memberi pengaruh dan variabel terikat yang dipengaruhi terhadap sebuah fenomena yang komplit. Pada tabel 5 variabel $X$ yang merupakan variabel budaya organisasi memberikan pengaruh terhadap variabel Y kinerja anggota yang dapat diketahui dari nilai $\mathrm{F}$ hitung 33,321 dan 0,000 sebagai nilai signifikasinnya yang berarti kurang dari 0,005 .

Tabel 6. Mengemukakan Pendapat

\begin{tabular}{cc}
\hline Pernyataan & Persentase \\
\hline $4=\mathrm{SS}$ & $60,4 \%$ \\
\hline $3=\mathrm{S}$ & $39,6 \%$ \\
\hline Total & $100,0 \%$ \\
\hline
\end{tabular}

Pada tabel 6 terdapat 53 orang $(100 \%)$ yang setuju bahwa senantiasa diperbolehkan untuk mengutarakan opini terkait setiap tugas yang mereka terima. Menurut salah satu anggota BEMP Ilmu Komunikasi UNJ bernama Alika Syachrani menyatakan bahwa ia senantiasa diberikan kesempatan untuk mengemukakan pendapat ketika sedang rapat.

Tabel 7. Bertindak Aktif

\begin{tabular}{cc}
\hline Pernyataan & Persentase \\
\hline $4=\mathrm{SS}$ & $62,3 \%$ \\
\hline $3=\mathrm{S}$ & $37,7 \%$ \\
\hline Total & $100,0 \%$ \\
\hline
\end{tabular}

Pada tabel 7 terdapat 53 orang (100\%) yang setuju, mereka senantiasa mendapat kebebasan melakukan tindakan aktif ketika mengerjakan tugas yang diberikan. Menurut Alika, ia senantiasa diberikan kebebasan untuk melakukan improvisasi dalam setiap pekerjaan ketika sedang melaksanakan tugas, namun tetap sesuai dengan prosedur yang sudah ditentukan.

Tabel 8. Memahami Target

\begin{tabular}{cc}
\hline Pernyataan & Persentase \\
\hline $4=\mathrm{SS}$ & $54,7 \%$ \\
\hline $3=\mathrm{S}$ & $45,3 \%$ \\
\hline Total & 100,0 \\
\hline
\end{tabular}


Pada tabel 8 terdapat 53 orang (100\%) yang setuju bahwa memiliki pemahaman mengenai target yang diharapkan oleh BEMP Ilmu Komunikasi UNJ dari anggotanya. Menurut Alika, dirinya memahami setiap target yang diharapkan, tanpa target yang jelas dia tidak akan bergabung ke dalam organisasi maupun kepanitiaan tersebut.

Tabel 9. Tingkat Kerja Sama

\begin{tabular}{cc}
\hline Pernyataan & Persentase \\
\hline $4=\mathrm{SS}$ & $43,4 \%$ \\
\hline $3=\mathrm{S}$ & $52,8 \%$ \\
\hline $2=\mathrm{TS}$ & $3,8 \%$ \\
\hline Total & 100,0 \\
\hline
\end{tabular}

Pada tabel 9 terdapat 51 orang $(96,2 \%)$ yang setuju bahwa tingkat kerja sama di antara sesama anggota telah berjalan dengan baik. Namun terdapat 2 orang $(3,8 \%)$ yang tidak setuju dengan pernyataan bahwa kerja sama antar anggota sudah berlangsung baik. Menurut Alika, setiap anggota sudah menjalan kerja sama serta mencapai target yang diinginkan dengan bai, oleh karena ituu program kerja maupun non program kerja BEMP ilmu komunikasi UNJ dapat terlaksana dengan baik.

Tabel 10. Dukungan yang Positif

\begin{tabular}{cc}
\hline Pernyataan & Persentase \\
\hline $4=\mathrm{SS}$ & $45,3 \%$ \\
\hline $3=\mathrm{S}$ & $52,8 \%$ \\
\hline $2=\mathrm{TS}$ & $1,9 \%$ \\
\hline Total & $100,0 \%$ \\
\hline
\end{tabular}

Pada tabel 10 terdapat 52 orang $(98,1 \%$ ) yang setuju bahwa ketua senantiasa menyampaikan dukungan positif kepada setiap tugas yang dikerjakan oleh anggota organisasi BEMP Ilmu Komunikasi UNJ dan terdapat 1 orang $(1,9 \%)$ yang tidak setuju bahwa ketua senantiasa memberikan dukungan yang positif terhadap setiap anggota dalam melaksanakan pekerjaan. Menurut Alika, tanpa dukungan dari ketua, setiap kegiatan baik program kerja maupun non program kerja BEMP Ilmu Komunikasi UNJ akan terasa sulit terlaksana tanpa adanya dukungan yang positif dari ketua.

Tabel 11. Pengawasan Kegiatan

\begin{tabular}{cc}
\hline Pernyataan & Persentase \\
\hline $4=\mathrm{SS}$ & $45,3 \%$ \\
\hline $3=\mathrm{S}$ & $49,1 \%$ \\
\hline $2=\mathrm{TS}$ & $5,7 \%$ \\
\hline Total & $100,00 \%$ \\
\hline
\end{tabular}

Pada tabel 11 terdapat 51 orang $(96,2 \%)$ setuju bahwa ketua senantiasa mengawasi tugas yang dikerjakan setiap anggota dan terdapat 1 orang $(1,9 \%)$ tidak setuju dengan pernyataan tersebut. Menurut Alika, tanpa adanya pengawasan dari ketua, maka setiap kegiatan baik program kerja maupun non program kerja akan mengalami kendala dalam menyelesaikannya hingga sukses. 
Tabel 12. Nilai-Nilai Pedoman Perilaku

\begin{tabular}{cc}
\hline Pernyataan & Persentase \\
\hline $4=\mathrm{SS}$ & $58,5 \%$ \\
\hline $3=\mathrm{S}$ & $39,6 \%$ \\
\hline $2=\mathrm{TS}$ & $1,9 \%$ \\
\hline Total & $100,0 \%$ \\
\hline
\end{tabular}

Pada tabel 12 terdapat 50 orang $(94,4 \%)$ yang setuju bahwa memahami nilai-nilai dan pedoman perilaku yang terdapat dalam BEMP Ilmu Komunikasi UNJ dan 3 orang lainnya $(5,7 \%)$ tidak setuju dengan pernyataan tersebut. Menurut Alika, tanpa memahami nilai-nilai yang menjadi pedoman dalam berperilaku dalam budaya organisasi, maka akan kesulitan dalam mengenali setiap karakter dari anggota organisasi yang berujung kepada sulitnya bekerja sama antara sesama anggota dalam melaksanakan kegiatan BEMP Ilmu Komunikasi UNJ.

Tabel 13. Apresiasi

\begin{tabular}{cc}
\hline Pernyataan & Persentase \\
\hline $4=\mathrm{SS}$ & $32,1 \%$ \\
\hline $3=\mathrm{S}$ & $64,2 \%$ \\
\hline $2=\mathrm{TS}$ & $3,8 \%$ \\
\hline Total & $100,0 \%$
\end{tabular}

Pada tabel 13 terdapat 52 orang $(96,2 \%)$ yang setuju bahwa apresiasi yang diberikan kepada setiap anggota organisasi dalam melaksanakan kegiatan BEMP Ilmu Komunikasi UNJ timbulnya motivasi dalam melakukan setiap kegiatan dan 1 orang $(1,9 \%)$ tidak menyetujuinya. Menurut Alika, tanpa apresiasi maka akan membuat setiap anggota merasa malas dalam melakukan setiap kegiatan yang diselenggarakan oleh BEMP Ilmu Komunikasi UNJ.

Tabel 14. Penyelesaian Konflik

\begin{tabular}{cc}
\hline Pernyataan & Persentase \\
\hline $4=\mathrm{SS}$ & $49,1 \%$ \\
\hline $3=\mathrm{S}$ & $45,3 \%$ \\
\hline $2=\mathrm{TS}$ & $5,7 \%$ \\
\hline Total & $100,0 \%$ \\
\hline
\end{tabular}

Pada tabel 14 terdapat 51 orang $(96,3 \%)$ yang setuju bahwa ketua senantiasa menyelesaikan konflik yang terdapat dalam organisasi BEMP Ilmu Komunikasi UNJ hingga tungas dan 2 orang lainnya (3,8\%) tidak setuju dengan pernyataan tersebut. Menurut Alika, selama menjadi anggota BEMP Ilmu Komunikasi UNJ, ketua senantiasa menyelesaikan konflik hingga selesai.

Tabel 15. Kebijakan

\begin{tabular}{cc}
\hline Pernyataan & Persentase \\
\hline $4=\mathrm{SS}$ & $52,8 \%$ \\
\hline $3=\mathrm{S}$ & $47,2 \%$ \\
\hline Total & $100,0 \%$ \\
\hline
\end{tabular}

Pada tabel 15 terdapat 51 orang $(94,4 \%)$ yang setuju bahwa setiap kebijakan yang diambil oleh ketua 
akan disosialisasikan kepada setiap anggota organisasi BEMP Ilmu Komunikasi UNJ dan 3 orang lainnya $(5,7 \%)$ tidak setuju dengan pernyataan tersebut. Menurut Alika, diambil akan disosialisasikan kepada setiap anggota organisasi BEMP Ilmu Komunikasi UNJ.

Tabel 16. Melaksanakan Pekerjaan Sesuai dengan Prosedur

\begin{tabular}{cc}
\hline Pernyataan & Persentase \\
\hline $4=\mathrm{SS}$ & $35,8 \%$ \\
\hline $3=\mathrm{S}$ & $62,3 \%$ \\
\hline $2=\mathrm{TS}$ & $1,9 \%$ \\
\hline Total & $100,0 \%$ \\
\hline
\end{tabular}

Pada tabel 16 terdapat 52 orang $(98,1 \%)$ orang yang setuju bahwa setiap anggota organisasi senantiasa mengerjakan setiap tugas yang diterima dengan memperhatikan prosedur yang ditentukan. Sedangkan, terdapat 1 orang $(1,9 \%)$ tidak setuju dengan setiap anggota organisasi senantiasa mengerjakan setiap ugas yang diterima dengan memperhatikan prosedur. Menurut Alika, ia senantiasa mengerjakan setiap tugas-tugasnya sesuai dengan prosedur yang ditentukan agar tidak kebingungan dan lebih tertib dalam mengerjakannya.

Tabel 17. Menyelesaikan Pekerjaan Sesuai Target
\begin{tabular}{cc}
\hline Pernyataan & Persentase \\
\hline $4=\mathrm{SS}$ & $58,5 \%$ \\
\hline $3=\mathrm{S}$ & $41,5 \%$ \\
\hline Total & $100,0 \%$ \\
\hline
\end{tabular}

Pada tabel 17 terdapat 53 orang (100\%) yang setuju bahwa setiap anggota organisasi BEMP Ilmu Komunikasi UNJ selalu menyelesaikan setiap pekerjaannya sesuai dengan target. Menurut Alika, ia selalu menyelesaikan setiap pekerjaannya sesuai dengan target agar setiap usahanya tidak terasa sia-sia.

Tabel 18. Memahami Pekerjaan

\begin{tabular}{cc}
\hline Pernyataan & Persentase \\
\hline $4=\mathrm{SS}$ & $32,1 \%$ \\
\hline $3=\mathrm{S}$ & $62,3 \%$ \\
\hline $2=\mathrm{TS}$ & $5,7 \%$ \\
\hline Total & $100,0 \%$ \\
\hline
\end{tabular}

Pada tabel 18 terdapat 51 orang $(94,4 \%)$ yang setuju bahwa setiap anggota sudah memahami setiap pekerjaan yang akan dikerjakan. Menurut Alika, ketika ia tidak memahami pekerjaan yang akan dikerjakan, ia akan bertanya kepada kakak tingkatnya dalam organisasi BEMP Ilmu Komunikasi UNJ atau bertanya kepada orang yang lebih berpengalaman, agar dapat memahami setiap pekerjaan yang akan dikerjakan.

Tabel 19. Memiliki Ide-Ide Baru

\begin{tabular}{cc}
\hline Pernyataan & Persentase \\
\hline $4=\mathrm{SS}$ & $39,6 \%$ \\
\hline $3=\mathrm{S}$ & $60,4 \%$ \\
\hline Total & $100,0 \%$ \\
\hline
\end{tabular}


Pada tabel 19 terdapat 53 orang (100\%) yang setuju bahwa setiap anggota memiliki ide-ide yang baru setiap melaksanakan pekerjaan. Menurut Alika, terkadang ia senantiasa menyampaikan ide-idenya kepada sesama anggota oganisasi, sehingga dengan adanya ide-ide yang baru, akan membuat setiap kegiatan berjalan dengan unik dan berbeda dari sebelumnya.

Tabel 20. Mampu Bekerja sama

\begin{tabular}{cc}
\hline Pernyataan & Persentase \\
\hline $4=\mathrm{SS}$ & $62,3 \%$ \\
\hline $3=\mathrm{S}$ & $37,7 \%$ \\
\hline Total & $100,0 \%$ \\
\hline
\end{tabular}

Pada tabel 20 terdapat 53 orang (100\%) yang setuju bahwa setiap anggota organisasi BEMP Ilmu Komunikasi UNJ mampu bekerjasama satu dengan yang lainnya. Menurut Alika, ia mampu bekerjasama dengan sesama anggota organisasi BEMP Ilmu Komunikasi UNJ, baginya dengan bekerjasama lebih baik dibandingkan bekerja secara mandiri.

Tabel 21

Bersedia Menerima Kritik dan Saran

\begin{tabular}{cc}
\hline Pernyataan & Persentase \\
\hline $4=\mathrm{SS}$ & $45,3 \%$ \\
\hline $3=\mathrm{S}$ & $52,8 \%$ \\
\hline $2=\mathrm{TS}$ & $1,9 \%$ \\
\hline Total & $100,0 \%$ \\
\hline
\end{tabular}

Pada tabel 21 terdapat 51 orang $(97,1 \%)$ yang setuju bahwa setiap anggota organisasi BEMP Ilmu Komunikasi UNJ dengan lapang menerima kritik dan saran yang dikatakan setiap anggota organisasi. Menurut Alika, ia menyadari bahwa kritik dan saran akan membuatnya semakin belajar agar menjadi lebih baik.

Tabel 22.Berinisiatif Menyelesaikan Pekerjaan

\begin{tabular}{cc}
\hline Pernyataan & Persentase \\
\hline $4=\mathrm{SS}$ & $49,1 \%$ \\
\hline $3=\mathrm{S}$ & $49,1 \%$ \\
\hline $2=\mathrm{TS}$ & $1,9 \%$ \\
\hline Total & $100,0 \%$ \\
\hline
\end{tabular}

Pada tabel 22 terdapat 51 orang ( 98,2\%) yang setuju bahwa setiap anggota organisasi BEMP Ilmu Komunikasi UNJ berinisiatif dalam menyelesaikan setiap pekerjaan yang diberikan. Sedangkan, terdapat 1 orang $(1,9 \%)$ tidak setuju bahwa setiap anggota organisasi memiliki inisiatif dalam menyelesaikan pekerjaannya. Menurut Alika, ia senantiasa berinisiatif menyelesaikan setiap pekerjaannya agar kerja sama dengan sesama anggota organisasi berjalan dengan baik. 


Tabel 23. Kemampuan Menjelaskan Pekerjaan
\begin{tabular}{cc}
\hline Pernyataan & Persentase \\
\hline $4=\mathrm{SS}$ & $47,2 \%$ \\
\hline $3=\mathrm{S}$ & $52,8 \%$ \\
\hline Total & $100,0 \%$ \\
\hline
\end{tabular}

Pada tabel 23 terdapat 53 orang (100\%) yang setuju bahwa setiap anggota organisasi BEMP Ilmu Komunikasi UNJ memiliki kemampuan dalam menjelaskan pekerjaan yang telah diberikan kepada orang lain. Menurut Alika, ia memiliki dedikasi yang tinggi kepada setiap pekerjaan yang telah diampunya, sehingga ia mampu menjelaskan pekerjaannya kepada orang lain.

Tabel 24. Jujur Dalam Melaksanakan Pekerjaan

\begin{tabular}{cc}
\hline Pernyataan & Persentase \\
\hline $4=\mathrm{SS}$ & $43,4 \%$ \\
\hline $3=\mathrm{S}$ & $50,9 \%$ \\
\hline $2=\mathrm{TS}$ & $5,7 \%$ \\
\hline Total & $100,0 \%$ \\
\hline
\end{tabular}

Pada tabel 24 terdapat 53 orang (100\%) yang setuju bahwa setiap anggota organisasi BEMP Ilmu Komunikasi UNJ jujur ketika mengerjakan setiap tugas yang telah diterima. Menurut Alika, ia selalu mengusahakan untuk bersikap jujur dalam melaksanakan setiap pekerjaannya, selain itu baginya dengan bersikap jujur artinya sama dengan menghargai kerja keras sesama anggota BEMP Ilmu Komunikasi UNJ.

Tabel 25Berpenampilan dengan Baik

\begin{tabular}{cc}
\hline Pernyataan & Persentase \\
\hline $4=\mathrm{SS}$ & $52,8 \%$ \\
\hline $3=\mathrm{S}$ & $47,2 \%$ \\
\hline Total & $100,0 \%$ \\
\hline
\end{tabular}

Pada tabel 25 terdapat 53 orang (100\%) yang berpenampilan dengan baik ketika sedang menghadiri rapat BEMP Ilmu Komunikasi UNJ. Menurut Alika, ia senantiasa berpenampilan dengan baik dan rapih ketika sedang menghadiri rapat, karena baginya hal tersebut merupakan salah satu bentuk menghargai setiap anggota organisasi BEM Ilmu Komunikasi UNJ yang menghadiri rapat.

\section{KESIMPULAN}

Adanya budaya dalam organisasi membantu anggota untuk memiliki nilai, norma, pedoman, serta acuan dalam melaksanakan dan mewujudkan visi dan misi dalam organisasi. Hal ini menunjukkan budaya dalam sebuah organisasi memegang peran yang penting terkait kesuksesan organisasi tersebut (Pratama 2012). Hasil yang diperoleh yaitu variabel $X$ yang merupakan variabel budaya organisasi memberikan pengaruh terhadap variabel $\mathrm{Y}$ yang merupakan kinerja anggota yang dapat diketahui dari nilai $\mathrm{F}$ hitung 33,321 dan 0,000 sebagai nilai signifikasinnya yang berarti kurang dari 0,005. Selain itu, terdapat data yang diperoleh dari kuesioner yang disebar pada anggota BEMP Ilmu Komunikasi UNJ yang menunjukkan bahwa 53 orang $(100 \%)$ yang setuju bahwa senantiasa mendapat kesempatan untuk mengutarakan opini pada setiap tugas yang diterima. Terdapat 53 orang (100\%) yang setuju bahwa 
senantiasa mendapat kebebasan melakukan tindakan aktif ketika mengerjakan tugas yang diberikan. Kemudian, sebanyak 53 orang (100\%) yang setuju bahwa memiliki pemahaman mengenai target yang diharapkan oleh BEMP Ilmu Komunikasi UNJ dari anggotanya. Sebanyak 51 orang $(96,2 \%)$ yang setuju bahwa tingkat kerja sama di antara sesama anggota telah berjalan dengan baik dan terdapat 2 orang $(3,8 \%)$ yang tidak setuju dengan pernyataan tersebut, sehingga memperlihatkan mayoritas setuju bahwa salah satu budaya dalam organisasi BEMP Ilmu Komunikasi UNJ, yaitu kerja sama antara sesama anggota berjalan dengan baik. Sebanyak 52 orang $(98,1 \%)$ setuju bahwa ketua senantiasa menyampaikan dukungan positif kepada setiap tugas yang dikerjakan oleh anggota organisasi BEMP Ilmu Komunikasi UNJ dan terdapat 1 orang $(1,9 \%)$ yang tidak setuju bahwa ketua senantiasa memberikan dukungan yang positif terhadap setiap anggota dalam melaksanakan pekerjaan. Sebanyak 51 orang $(96,2 \%)$ setuju bahwa ketua senantiasa mengawasi tugas yang dikerjakan oleh anggota dan terdapat 1 orang (1,9\%) tidak menyetujui pernyataan itu. Sebanyak 50 orang $(94,4 \%)$ yang setuju bahwa memahami nilai-nilai dan pedoman perilaku yang terdapat dalam BEMP Ilmu Komunikasi UNJ dan 3 orang lainnya (5,7\%) tidak setuju dengan pernyataan tersebut. Sebanyak 52 orang $(96,2 \%)$ yang setuju bahwa apresiasi yang diberikan kepada setiap anggota organisasi dalam melaksanakan kegiatan BEMP Ilmu Komunikasi UNJ timbulnya motivasi dalam melakukan setiap kegiatan dan 1 orang $(1,9 \%)$ tidak menyetujuipernyataan tersebut. Sebanyak 51 orang $(96,3 \%)$ yang setuju bahwa ketua senantiasa menyelesaikan konflik yang terdapat dalam organisasi BEMP Ilmu Komunikasi UNJ hingga tungas dan 2 orang lainnya (3,8\%) tidak setuju dengan pernyataan tersebut. Kemudian, sebanyak 51 orang $(94,4 \%)$ yang setuju bahwa setiap kebijakan yang diambil oleh ketua akan disosialisasikan kepada setiap anggota organisasi BEMP Ilmu Komunikasi UNJ dan 3 orang lainnya $(5,7 \%)$ tidak setuju dengan pernyataan tersebut.

Data tersebut menunjukkan adanya budaya yang baik, terdapat nilai, norma, pedoman, serta acuan bagi setiap anggota dalam organisasi BEMP Ilmu Komunikasi UNJ. Sebagai pengaruh dari budaya tersebut, data yang terkumpul dari kuesioner yang disebar menunjukkan bahwa mayoritas anggota BEMP Ilmu Komunikasi senantiasa mengerjakan setiap pekerjaan yang diterima sesuai dengan prosedur yang telah ditentukan dan disepakati, anggota organisasi selalu menyelesaikan setiap pekerjaannya sesuai dengan target, memahami setiap pekerjaan yang akan dikerjakan, memiliki ide-ide baru setiap melaksanakan pekerjaan, setiap anggota mampu bekerja sama satu dengan yang lainnya, dengan lapang menerima setiap kritik dan saran yang disampaikan oleh setiap anggota organisasi, berinisiatif dalam membereskan setiap tugas yang diterima, mampu menjelaskan tugas yang telah diberikan kepada orang lain, jujur dalam mengerjakan setiap tugas yang telah diterima, berpenampilan dengan baik ketika sedang menghadiri rapat BEMP Ilmu Komunikasi UNJ.

\section{SARAN}

Berdasarkan hasil tersebut, anggota organisasi BEMP Ilmu Komunikasi UNJ dapat meningkatkan kerja sama antar anggota dan memahami nilai-nilai dalam organisasi. Kemudian, bagi ketua untuk dapat memberikan dukungan positif, meningkatkan pengawasan terhadap pekerjaan anggota, memberi apresiasi kepada anggota, menyelesaikan konfli, dan mensosialisasikan kebijakan yang diambil kepada anggota organisasi. 


\section{DAFTAR PUSTAKA}

[1]. Amanda, Enno Aldea, Satrijo Budiwibowo, And Nik Amah. 2017. "Pengaruh Budaya Organisasi Terhadap Kinerja Karyawan Di Pdam Tirta Taman Sari Kota Madiun.” Assets: Jurnal Akuntansi Dan Pendidikan 6(1):1.

[2]. Creswell, John W. 2014. Research Design: Qualitative, Quantitative, And Mixed Method Approaches. Fourth Edi. California: Sage.

[3]. Imron, Imron. 2019. "Analisa Pengaruh Kualitas Produk Terhadap Kepuasan Konsumen Menggunakan Metode Kuantitatif Pada Cv. Meubele Berkah Tangerang.” Indonesian Journal On Software Engineering (Ijse) 5(1):19-28.

[4]. Jamaluddin, Rudi Salam, Harisman Yunus, And Haedar Akib. 2017. "Pengaruh Budaya Organisasi Terhadap Kinerja Pegawai Pada Dinas Pendidikan Provinsi Sulawesi Selatan.” Jurnal Administrare 4(1):25.

[5]. Malhotra, Naresh K. 2010. Marketing Research: An Applied Orientation. Sixth. New Jersey: Pearson Education Inc.

[6]. Marliani, Lina. 2019. "Peranan Budaya Organisasi Dalam Mewujudkan Kinerja Suatu Organisasi." Journal Of Chemical Information And Modeling 53(9):1689-99.

[7]. Muhammad, Ezra Zhafran Giani, And Mochammad Djudi Mukzam. 2017. "Pengaruh Budaya Organisasi Terhadap Kinerja Karyawan (Studi Pada Karyawan Bank Bri Kantor Cabang Tuban).” 53(1):89-95.

[8]. Muslianti. 2018. "Pengaruh Budaya Organisasi Himpunan Mahasiswa Program Studi Pendidikan Ips Terhadap Pembentukan Karakter Mahasiswa Program Studi Pendidikan Ips Fis Unm.”

[9]. Neuman, W. Lawrence. 2014. Basics Of Social Research: Qualitative \& Quantitative Approaches. Third Edit. Pearson Education Limited.

[10].Pratama, Yoga. 2012. "Pengaruh Budaya Organisasi Terhadap Kinerja Pegawai Pada Kantor Kecamatan Nanggung Kabupaten Bogor.” 1-136.

[11].Rizaldi, A. R. 2019. "Kinerja Pegawai Dalam Tinjauan Budaya Organisasi (Studi Kasus)." Seiko: Journal Of Management \& Business 2(2):131-44.

[12].Rosvita, Vivin, Endang Setyowati, And Zaenal Fanani. 2017. "Pengaruh Budaya Organisasi Terhadap Kinerja Karyawan.” Indonesia Jurnal Farmasi 2(1):14-20.

[13].Sagita, Alinvia Ayu, Heru Susilo, And Muhammad Cahyo. 2018. "Pengaruh Budaya Organisasi Terhadap Kinerja Karyawan Dengan Motivasi Kerja Sebagai Variabel Mediator (Studi Pada Pt Astra Internasional, Tbk-Toyota (Auto2000) Cabang Sutoyo Malang).” Jurnal Administrasi Bisnis (Jab)|Vol $57(1)$. 
[14].Sekaran, Uma, And Roger Bougie. 2016. Research Methods For Business. Seventh Ed. United Kingdom: John Wiley \& Sons.

[15].Wardani, Rodiathul Kusuma, Djudi M. Mukzam, And Yuniadi Mayowan. 2016. "( Studi Pada Karyawan Pt Karya Indah Buana Surabaya ).” Jurnal Administrasi Bisnis (Jab) 31(1):58-65. 